\title{
The effect of the addition of polypropylene fibres on improvement on concrete quality
}

\author{
Alina Pietrzak ${ }^{1 *}$, and Matgorzata Ulewicz $^{1}$ \\ ${ }^{1}$ Czestochowa University of Technology, Faculty of Civil Engineering, Poland
}

\begin{abstract}
Concrete serves as one of the most important construction materials, which thanks to its resistance and durability, gives total freedom in using it in building industry, and by extension in defining urban areas. Despite numerous advantages (ease of handling, high compressive strength, low production cost, heat resistance) it also has many disadvantages, including low tensile strength as well as sensitivity to destructive action of chemical agents. A constant growth in expectations concerning increasing the quality of concrete led to its polymer modification, whose aim was to eliminate above-mentioned disadvantages. The scope of the present research involved designing and making of concrete mixtures modified by $19,30,40$ and $60 \mathrm{~mm}$ long polypropylene fibres. For the experiment the authors used: Portland cement CEM I 42.5R, sand, gravel aggregate of the 2-8 and 8-16 fractions, water, Master Pozzolith STD plasticizer and polypropylene fibres of various length. The authors made 4 series of concrete samples modified by fibres, for which the following factors have been assigned: compression strength after 7, 28 and 56 days of maturing as well as absorptivity, volumetric density and frost resistance after 100 cycles of freezing and thawing.
\end{abstract}

\section{Introduction}

Concrete and steel are the most commonly used construction materials, which form the image of the contemporary architecture. A constant growth of the quality of these products is caused by both an increase in users' expectations and an increase in demands determined by certain regulations [1-3]. Polymers, as modifiers, have been used to improve the concrete quality for over fifty years [4-6]. The group of polymer concretes include: resin concrete (PC), polymer-cement concrete (PCC), polymer impregnated concrete (PIC) [6-9].

Concrete modified by polypropylene fibres is used for making industrial flooring, road and airport surfaces, and prefabricated thin-walled elements. The main advantage of using such fibres is to prevent the occurrence of anti-shrinkage cracks in 'young' maturing concrete. However, having reached the resistance designed and the modulus of elasticity such fibres cease to work. Then, the stresses are transferred by concrete itself or main anchoring bars [9, 10-12]. The aim of the paper was to determine the influence of the length of the polypropylene fibre on the basic properties of concrete.

\footnotetext{
*Corresponding author: apietrzak@bud.pcz.pl
} 


\section{Materials and the research methodology}

For the experiment the authors used: Portland cement CEM I 42.5R, sand, gravel aggregate of the 2-8 and 8-16 $\mathrm{mm}$ fractions, water, Master Pozzolith STD plasticizer and polypropylene fibres of various length (Table 1).

Table 1. Properties of polypropylene fibres used in the study.

\begin{tabular}{|c|c|c|c|}
\hline \multirow{2}{*}{ Fibre designation } & \multicolumn{3}{|c|}{ Properties } \\
\hline & Shape & Colour & Fibre length, mm \\
\hline A1 & \multirow{4}{*}{ bundle } & \multirow{4}{*}{ white } & $19 \pm 1.5$ \\
\hline $\mathrm{A} 2$ & & & $30 \pm 1.5$ \\
\hline A3 & & & $40 \pm 1.5$ \\
\hline A4 & & & $60 \pm 1.5$ \\
\hline
\end{tabular}

5 series of samples were made. Control concrete sample with the $\mathrm{w} / \mathrm{c}=0.55$ ratio with the addition of plasticizer in the amount of $0.3 \%$ of the cement bulk - (SK) series. In the subsequent attempts the control concrete was modified with polypropylene fibres (A1-A4 series) in the amount of $0.9 \mathrm{~kg} / \mathrm{m}^{3}$. Samples for measuring compressive strength were made in forms according to requirements of the Norm PN-EN 12390-1. For all series of concrete samples there were twelve $15 \times 15 \times 15 \mathrm{~cm}$ cubic samples and twelve $10 \times 10 \times 10 \mathrm{~cm}$ samples formed according to Norm PN-EN 12390-2. The experiment of durability of compressive strength was conducted after 7,28 and 56 days of sample maturing under laboratory conditions according to Norm PN-EN 206:2014 Concrete - "Specification, performance, production and conformity". The experiment was carried out by mean of Toni Technik type 2030 testing machine according to the Norm.

\section{Research results}

With the experimentally assumed water/cement ratio the concrete mixture was designed in the way to gain appropriate consistency and workability. For the control concrete series the S3 consistency was assumed (slump within 100-150 mm). The research results on the compression strength, absorptivity and concrete density for particular series are presented in Table 2. The average compressive strength of the control concrete series $(1 \mathrm{~K})$ measures after 7 days equalled $\mathrm{f}_{\mathrm{cm}}=38.2 \mathrm{MPa}$. Adding polypropylene fibres caused a slight increase in average compressive strength for all modified series. After 7 days of maturing, the biggest, $4.2 \%$ increase of compressive strength in relation to the control concrete series was observed in A4 series. The smallest, $0.2 \%$ increase in compressive strength was examined in A1 series. The average compressive strength of the control concrete series $(1 \mathrm{~K})$, measures after 28 days $\mathrm{f}_{\mathrm{cm}}=46.7 \mathrm{MPa}$. In both concrete series (A1 and A2) the average compressive strength was on the similar level as in the control series and it equalled 46.8 $\mathrm{MPa}$. An increase of the compressive strength in relation to the $1 \mathrm{~K}$ series was noticed in $\mathrm{A} 3$ and A4 concrete series ( $0.9 \%$ and $1.8 \%$, respectively).

The average compressive strength of the control concrete series $(1 \mathrm{~K})$, measures after 56 days of maturing $\mathrm{f}_{\mathrm{cm}}=46.7 \mathrm{MPa}$. In all concrete series (A1 and A4) modified by fibres the 
average compressive strength was noticed. The increase equalled $0.13 \%, 0.8 \%, 0.3 \%$ and $4.1 \%$, respectively in relation to the $1 \mathrm{~K}$ series.

On the basis of the methodology included in Norm PN-88/B-06250 Plain Concrete, an experiment of absorbability of particular series was conducted and the findings are presented in Table 2. According to the above-mentioned Norm, the absorbability of concrete exposed to environmental influences should not be bigger than $5 \%$. However, for concrete protected from direct weather conditions should not be bigger than $9 \%$. Both the control concrete and the polypropylene fibres modified concrete reached the absorbability within $5.5-5.7 \%$.

Table 2. Results of compression strength, absorptivity and concrete density for particular series.

\begin{tabular}{|c|c|c|c|c|c|}
\hline \multirow{2}{*}{$\begin{array}{l}\text { Concrete } \\
\text { series }\end{array}$} & \multicolumn{3}{|c|}{ Average compression strength, $f_{c m}(\mathrm{MPa})$} & \multirow{2}{*}{$\begin{array}{l}\text { Absorptivity, } \\
\boldsymbol{n}_{w}(\% \text { masy })\end{array}$} & \multirow{2}{*}{$\begin{array}{c}\text { Volumetric } \\
\text { density, } \\
\rho\left(\mathrm{kg} / \mathrm{m}^{3}\right)\end{array}$} \\
\hline & $\begin{array}{l}\text { after } 7 \text { days } \\
\text { of maturing }\end{array}$ & $\begin{array}{c}\text { after } 28 \text { days } \\
\text { of maturing }\end{array}$ & $\begin{array}{c}\text { after } 56 \text { days } \\
\text { of maturing }\end{array}$ & & \\
\hline $1 \mathrm{~K}$ & 38.2 & 46.7 & 51.4 & 5.5 & 2283 \\
\hline A1 & 38.2 & 46.8 & 51.4 & 5.7 & 2247 \\
\hline A2 & 39.0 & 46.8 & 51.8 & 5.7 & 2238 \\
\hline A3 & 38.5 & 47.5 & 51.5 & 5.7 & 2277 \\
\hline A4 & 39.7 & 47.9 & 53.5 & 5.5 & 2287 \\
\hline
\end{tabular}

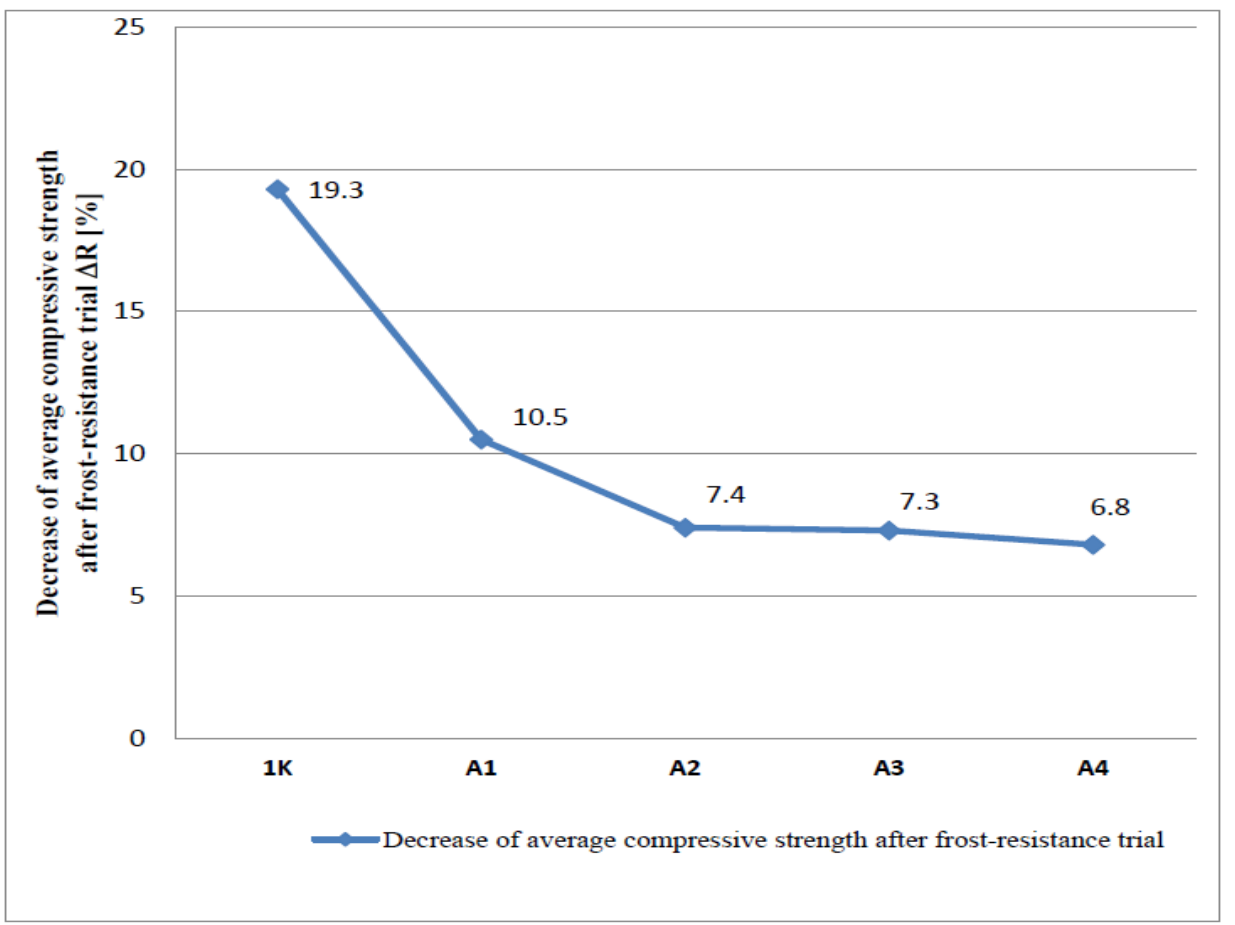

Fig. 1. Decrease of average compressive strength of particular concrete series after frost-resistance trial. 
Using direct method (PN-88/B-06250) the authors conducted a study of concrete frostresistance for a F100 resistance class. The results are presented on Figure 1. The analytical determination is taken as positive if after carrying out of $n$ cycles of freezing and thawing, required by certain frost resistance class: the average decrease of compressive strength does not exceed $20 \%$, the average loss in mass does not exceed $5 \%$ and none of the examined samples breaks or scratches. The decrease of resistance for alternate freezing and thawing of the control series equalled $19.3 \%$. As presented in Figure 1, the A1=A4 concrete series modified by polypropylene fibres showed much smaller decrease of resistance for alternate freezing and thawing in relation to the control series. The smallest decrease of strength after concrete frost-resistance trial was noticed in A4 series and it equalled $6.8 \%$. The loss of mass for all concrete series was in the range of between $0.15-0.31 \%$.

\section{Conclusions}

Concrete series modified by 19, 30, 40 and $60 \mathrm{~mm}$ long polypropylene fibres obtained comparable drainage durability in relation to the control series. Along with the growth of the fibre length in the range of between $19-60 \mathrm{~mm}$, a slight increase in compressive strength of concrete, equalling 1.2\%, was noticed after 28 days (and 1.45 after 56 days). Series of concrete modified by polypropylene fibres demonstrated better resistance to freezing and thawing, as they obtained a smaller decrease in compressive strength in relation to the control series. The smallest decrease of compressive strength, equalling $6.8 \%$, after frostresistance trials demonstrated concrete samples containing fibres of $60 \mathrm{~mm}$ length.

\section{Acknowledgment}

The authors thank Wigolen S.A. from Czestochowa (Poland) for providing research material.

\section{References}

1. M. Nowicka-Skowron, R. Ulewicz, $24^{\text {th }}$ International Conference on Metallurgy and Materials(1707-1712, 2015)

2. A. Shahnawaz, H.S. Sharma, International Journal of Engineering Science and Computing, 7 (2017)

3. S. Kakooei, M. Hazizan Akil, M. Jamshidi, J. Rouhi, Constr Build Mater, 27, 1 (2012)

4. M. Ulewicz, J. Selejdak, S. Borkowski, M. Jagusiak-Kocik, $22^{\text {nd }}$ International Conference on Metallurgy and Materials (1926-1931, 2013)

5. T. Aly, J.G. Sanjayan, F. Collins, Mater Struc, 41 (2008)

6. S. Chandra, $8^{\text {th }}$ International Congress on Polymers in Concrete (3-11, 1995)

7. L. Czarnecki, CWB, 2 (2010)

8. K.S. Yeon, L. Youn-Su,n B. Lee, C. Kim, 10th International Congress on Polymers in Concrete (2001).

9. M.A. Galicki, BTA, 2 (2009)

10. T. Zuk, J. Pietraszek, M. Zenkiewicz, Polimery, 61, 519 (2016)

11. M. Zenkiewicz, T. Zuk, J. Pietraszek, Przem. Chem., 95, 1687 (2016)

12. M. Zenkiewicz, T. Zuk, J. Pietraszek, P. Rytlewski, K. Moraczewski, M. Stepczynska, Polimery, 61, 835 (2016) 